\title{
Comparative efficacy of endophytic versus foliar application of the entomopathogenic fungus Beauveria bassiana against the crucifer diamondback moth larvae for sustainable cabbage protection
}

\author{
Gabriel A. HEVIEFO ${ }^{1 *}$, Seth W. NYAMADOR ${ }^{2}$, Benjamin D. DATINON ${ }^{1}$, \\ Isabelle A. GLITHO ${ }^{2}$ and Manuele TAMÒ ${ }^{1}$
}

${ }^{1}$ International Institute of Tropical Agriculture, 08 BP 932 Tripostal, Cotonou, Benin.

${ }^{2}$ Applied Entomology Laboratory, Faculty of Sciences, University of Lomé, 01 BP 1515 Lomé 1, Togo.

${ }^{*}$ Corresponding author; Tel: + 22997874037 / + 22964086440

E-mail: g.heviefo@cgiar.org

\section{ACKNOWLEDGMENTS}

Our acknowledgments to the International Institute of Tropical Agriculture (IITA), Benin Station for financial support of this study.

\begin{abstract}
In recent investigations, Beauveria bassiana has been reported to be pathogenic to insect, endophytically colonize cabbage plants and may, therefore, be an alternative to chemical control of the diamondback moth, Plutella xylostella. In this study, the comparative efficacy of endophytic and foliar application of B. bassiana was assessed on different larval instars of P. xylostella. Cabbage plants were inoculated with $B$. bassiana conidia using seed coating and root soaking methods. Six weeks after plant endophytic inoculation, larval instars 2,3 and 4 of $P$. xylostella were released on endophytic plant leaves without fungal spraying, on non-endophytic leaves sprayed immediately with fungal formulation and on untreated control leaves. Our results indicate that the average mortality rates of larval instars 2,3 and 4 were significantly higher $(P<0.0001)$ on plants colonized by the endophyte than non-inoculated, untreated control plant. Similarly, significant differences were obtained between the foliar spraying of the fungus (corrected mortalities $\geq 96.72 \%$ ) and the endophytic applications (corrected mortalities $\leq 57.61 \%$ ). In endophytic treatments, larval mortality rates varied with larval age. Further investigations are needed to elucidate the cellular and molecular mechanisms of B. bassiana endophytism in cabbage.
\end{abstract}

(C) 2020 International Formulae Group. All rights reserved.

Keywords: Fungal endophyte, foliar application, cabbage plant, Plutella xylostella, larval mortality, cadaver sporulation.

\section{INTRODUCTION}

Cabbage, Brassica oleracea L. (Brassicaceae) is one of the most common vegetable crops grown worldwide and is becoming an economically important crop in Benin and in other West African countries (Godonou et al., 2009; Komlan et al., 2014).
The major constraints to cabbage production are insect pests that severely limit its marketable yields (Gnago et al., 2010; Mondedji et al., 2014). The diamondback moth Plutella xylostella L. (Lepidoptera: Plutellidae) is one of the most devastating and pesticideresistant insect pests of cabbage (Agboyi et al., 
2016). It has a short life cycle; it produces a very high number of individuals per generation and has multiple generations per year (more than 20 generations in the tropics). Plutella xylostella is a key pest of cabbage plants in Africa (Mondedji, 2010); therefore, its management is essential for maintaining the high levels of productivity required to meet the demand. However, the approaches used to increase crops production, rely mainly on chemical pesticides (Sane et al., 2018), with the major side-effect of inducing pesticide resistance in $P$. xylostella, thereby leading to the vicious circle of more frequent applications (Gnago et al., 2010; James et al., 2010; Tidjani et al., 2018). In Benin, vegetable growers apply two different synthetic insecticides including bifenthrin and deltamethrin for $P$. xylostella control on cabbage plants, with up to 19 applications during the three months of crop growth prior to harvest (James et al., 2010). Nevertheless, some growers also use endosulfan, a banned chemical insecticide usually sprayed on cotton plants, to protect their cabbage crop, without caring for of the intoxication risk to humans.

Hence, a more sustainable pest control approach is called for, which should be based, as much as possible, on the utilization and preservation of natural enemies (Tamò et al., 2012; Liu et al., 2014). In that respect, biological control methods have been developed against $P$. xylostella and were based mainly on the use of hymenopteran parasitoids such as Cotesia plutellae Kurdjumov (Hymenoptera: Braconidae) and Diadegma semiclausum Hellen (Hymenoptera: Ichneumonidae) (Kfir, 2005). Previously, Bacillus thuringiensis $(\mathrm{Bt})$ formulations have been used against $P$. xylostella for many years but their repeated and indiscriminate applications have quickly led to the appearance of resistance (Cheema et al., 2011).

Similarly, water suspensions of $B$. bassiana conidia were sprayed at the dose rate of $1 \mathrm{~kg}$ per hectare to control P. xylostella, but applications must be repeated several times during the cabbage production cycle of nearly 3 months (Godonou et al., 2009). Moreover, the cost of $1 \mathrm{~kg}$ of $B$. bassiana conidia powder ranges between 300 and 400 US\$ (Heviefo, unpublished data), making this control option totally unaffordable for subsistence farmers.

The interest to endophytic microorganisms increased only during the last 20 years, when their capacity to protect their host-plants against insect pests and pathogens has been demonstrated (Vega et al., 2008). Mutualistic associations between plants and endophytic fungi are very common in natural and agricultural ecosystems (Rasmussen et al., 2012). By living in symbiosis with their hostplants, endophytic fungi can produce metabolic products that negatively impact herbivorous organisms including arthropod pests (Benkhelil et al., 2004). Indeed, the presence of endophytic microorganisms in their respective host-plants resulted in the reduction of insect attacks (Azevedo et al., 2000). Isolates of $B$. bassiana are known to produce numerous secondary metabolites such as beauvericin, beauverolides, bassianolides, oosporein, cyclosporine $\mathrm{A}$ and oxalic acid with antibacterial, antifungal, cytotoxic and insecticidal activities (Ownley et al., 2010). Apart from its direct pathogenic activity on $P$. xylostella (Godonou et al., 2009), B. bassiana has recently been reported as being able to endophytically colonize cabbage plant (Heviefo et al., 2017), thereby opening new opportunities for using this organism in a novel biocontrol approach. In the present study, we assessed the pathogenicity of $B$. bassiana applied as foliar spray and an endophyte through seed coating and root soaking to the diamondback moth, $P$. xylostella.

\section{MATERIALS AND METHODS \\ Study sites}

The experiments were conducted in laboratory and screen house at the Benin station of the International Institute of Tropical Agriculture (IITA) located at the North of Cotonou (N 06 ${ }^{\circ} 5^{\prime} 15.6^{\prime \prime}$, E 002 ${ }^{\circ} 19^{\prime} 41.1^{\prime \prime}$ and Alt. $20 \mathrm{~m}$ ). The experimental conditions were set at $25 \pm 1{ }^{\circ} \mathrm{C}$ and $75 \%-90 \% \mathrm{RH}$ in the laboratory. In the screen house, temperatures fluctuated between $23.3 \pm 0.2{ }^{\circ} \mathrm{C}$ and $33.8 \pm$ $0.3^{\circ} \mathrm{C}$ whereas relative humidity varied from $70.5 \pm 1.5 \%$ to $97 \pm 0.2 \%$. 


\section{Fungal isolate}

The $B$. bassiana isolate used in all the experiments was $\mathrm{Bb} 11$, isolated from specimens of the cereal stemborer Sesamia calamistis Hampton (Lepidoptera: Noctuidae) collected at the village of Penessoulou (Northern Benin). This strain was selected based on results of field spray trials that demonstrated its virulence against $P$. xylostella and Psara basalis W. (Lepidoptera: Pyralidae). (James et al., 2006; Godonou et al., 2009). Production of the dry conidia started first with a fermentation phase in a liquid medium composed of $20 \mathrm{~g}$ of sugar, $20 \mathrm{~g}$ of brewery yeast and one litre of tap water during three days on rotary shaker to produce blastospores. The blastospore solution was used to inoculate rice grains in plastic balloons to induce the development of conidia. The conidia were subsequently extracted from the rice grains and dried indoors on a tray following the procedure described by Heviefo et al. (2018). A standard germination test was carried out and viability of conidia (percentage of germination) was calculated using the following formula developed by LUBILOSA, 1996:

$\mathrm{V}=[a /(a+b)] \times 100$,

where a was the number of germinated spores, $\mathrm{b}$ the number of non-germinated spores,

$\mathrm{V}$ the viability of conidia.

\section{Insect colonies}

Adults and larvae of $P$. xylostella were collected from different cabbage production fields near Cotonou in southern Benin. Larvae were reared on cabbage plants in mesh cages in a laboratory at IITA-Benin. Adult insects were fed with honey solution (10\%) and were allowed to oviposit on cabbage leaves in mesh cages where embryonic and larval development occurred.

\section{Cabbage variety}

The cabbage variety used in the experiments was K-K Cross premium, Hybrid imported from Japan. The seeds were purchased in local seed stores, Bénin semences (Abomey-calavi) and Gbegamey (Cotonou).

\section{Determination of the endophytic virulence of B. bassiana on P. xylostella}

These experiments were conducted in a screen house at $23.3 \pm 0.2{ }^{\circ} \mathrm{C}$ to $33.8 \pm 0.3^{\circ} \mathrm{C}$ and $70.5 \pm 1.5 \%$ to $97 \pm 0.2 \%$ HR. Endophytic colonisation of the cabbage plants by $B$. bassiana was induced by either seed coating and root soaking (Heviefo et al., 2017). The virulence of the endophytic $B$. bassiana on larval instars 2, 3 or 4 of $P$. xylostella was tested separately in six different treatments as follows:

Treatment 1 (Endo 1): $10 \mathrm{~g}$ of cabbage seeds were coated with $4 \mathrm{~g}$ of $B$. bassiana conidia powder and $6 \mathrm{ml}$ of tap water mixed with Tween 80 (Polyoxyethylene (20) sorbitan mono-oleate) was added to allow spores to become hydrophilic when they adhered. Tween 80 usually facilitates the homogenization of imperfect fungi in water formulations (LUBILOSA, 1996). The Coated seeds were sown but seedlings were not transplanted after emergence;

Treatment 2 (Endo 2): cabbage seeds coated as in treatment 1 but seedlings were transplanted into fresh pots;

Treatment 3 (Endo 3): cabbage seeds coated as treatment 1 but seedling roots dipped in $B$. bassiana conidia powder prior to transplanting; Treatment 4 (Endo 4): cabbage seeds not coated, but simply immersed in Tween-water before sowing. After growth, seedlings roots were dipped in $B$. bassiana conidia powder prior to transplantation;

Treatment 5 (foliar spray): cabbage seeds not coated before sowing and roots were not dipped in $B$. bassiana conidia powder; however, plants were sprayed with a $B$. bassiana formulation $\left(10^{8}\right.$ conidia $\mathrm{ml}^{-1}$ of Tween-water), using a hand-sprayer, immediately before releasing $P$. xylostella larvae.

Treatment 6 (control): cabbage seeds were not coated; but simply immersed in Tweenwater before sowing; roots were not dipped in B. bassiana conidia powder; plants were sprayed with Tween-water.

For each treatment including the control, three cabbage seedlings were sown 
individually in plastic pots (5 1 capacity) containing $4 \mathrm{~kg}$ of compost obtained from IITA-Benin's vegetable garden. On each cabbage plant (i.e. seedling), 20 larvae of the same instar were deposited on the leaves after checking that stems and leaves were well colonized by the endophyte $B$. bassiana following the detection and re-isolation methods described by Heviefo et al. (2017), six weeks after inoculation. Each potted plant was enclosed in a fine mesh cage to avoid larval escape. Insect mortality or pupation were observed and recorded daily. Larval cadavers were put in plastic Petri dishes $(9 \mathrm{~cm}$ diameter) containing a humidified sterilized paper towel and incubated at $25 \pm 1{ }^{\circ} \mathrm{C}$ for fungal sporulation while pupae were kept at $26 \pm 1{ }^{\circ} \mathrm{C}$ for adult emergence. The experiment was replicated three times under the same conditions. Larval instars 2, 3 and 4 were separately used.

Natural cumulative percentages of larval mortalities data were corrected using Abbott's formula (Abbott, 1925) and were used for comparison among treatments:

$C m=\left(1-\frac{n T r}{n C o}\right) \times 100$

$\mathrm{Cm}$ is corrected mortality,

$n T r$ is number of surviving treated larvae after treatment,

$n C o$ is number of surviving larvae in the control treatment.

\section{Data analysis}

Larval mortality rate was expressed as the percentage of dead larvae within the total number of larvae deposited on the plant. The sporulation rate was expressed as the percentage of larval cadavers from which fungus emerged out of the total number of cadavers.

Larval mortality or sporulation rates were compared among treatments using Analysis of Variance with SAS software, version 9.2. Cumulative mortality and sporulation rates were transformed using Arcsine square root values before statistical analyses. When Anova revealed significant differences, treatment larval mortality or sporulation means were separated using the Student-Newman-Keuls (SNK) multi-range test.

\section{RESULTS \\ Larval mortality}

The temporal trends of the corrected cumulative mortalities caused by $B$. bassiana in the different treatments are presented in Figures 1-3. For all larval instars, mortalities started two days after larval deposit and increased throughout the duration of the experiments. However, mortality rates increased faster for the foliar application, which induced the highest overall mortality rates throughout the experiments as compared to the endophytic inoculation (Figures 1-3). The mortality rates of larval instars 2, 3 and 4 were significantly higher $(\mathrm{df}=4 ; P<0.001)$ on plants colonized by the endophyte than noninoculated, untreated control plant.

As presented in Table 1, fungal endophytic treatments caused larval corrected mortality ranging from 38.27 to $57.61 \%$ in larval instar 2, 30.58 to $40.65 \%$ in larval instar 3 , and 16.67 to $26.67 \%$ in larval instar 4; while conidia applied in water formulation (i.e. foliar spray) induced $100 \%$ mortality in larval instar $2,98.78 \%$ in larval instar 3 and $96.72 \%$ in larval instar 4.

The foliar application of fungus caused significantly higher mortality of all larval instars tested $(\mathrm{df}=4 ; P<0.001 \%)($ Table 1$)$ than endophytical application. Endophytical treatment 3 (Endo 3) of B. bassiana induced significantly higher corrected mortality to larval instars $2(57.61 \%)$ compared to larval instar $3(40.65 \%)$ and instar $4(18.38 \%)(\mathrm{df}=$ $2 ; \mathrm{F}=75.25 ; P<0.0001)$. Natural mortalities of $8.8 \%, 10.5 \%$ and $3.3 \%$ were also observed respectively for larval instar 2, 3 and 4 in the untreated control and were used to correct treatments mortalities.

Endophyte applied in Treatment 3 (Endo 3: seeds coated and roots soaked) caused significantly higher mortality to $P$. xylostella larval instar $2(57.61 \pm 2.15 \%)$ than Treatment 1 (Endo 1: seeds coated simply and not replanted $)(38.27 \pm 3.93 \%)(\mathrm{df}=4 ; \mathrm{F}=8.24 ; P$ $<0.0001)$. Corrected mortalities of the second 
instar (Table 1) did not differ significantly among Endo 1 (38.27 $\pm 3.93 \%)$, Endo 2 (42.77 $\pm 4.81 \%)$ and Endo $4(45.33 \pm 5.52 \%)(\mathrm{df}=3$; $\mathrm{F}=3.51 ; P<0.09$ ). As for larval instar 3 , corrected mortality rates did not differ significantly among all endophytic treatments six days after application $(\mathrm{df}=3 ; \mathrm{F}=1.22 ; P<$ 0.38 ) (Table 1). Similarly, larval stage 4 corrected mortality values were not significantly different among endophytic treatments $(\mathrm{df}=3 ; \mathrm{F}=1.30 ; P<0.36)$. With respect to the influence of larval age, the corrected mortality rates varied with larval instar, where larval instar 4 recorded the lowest corrected mortality rates (Table 1). In the treatment 3 (Endo 3), younger instars displayed higher corrected mortalities than elder ones ( $\mathrm{df}$ $=2 ; \mathrm{F}=75.25 P<0.0001)$.

\section{Fungal sporulation}

In the foliar applications of B. bassiana, mean sporulation rates ranged from $93.33 \pm$
$5.44 \%$ to $94.70 \pm 2.32 \%$; while the mean sporulation rates ranged from $7.58 \pm 3.36 \%$ to $32.66 \pm 13.63 \%$ in the endophytic treatments (Table 2). No sporulations were observed on dead larvae in the untreated control. Foliar applications of $B$. bassiana induced significantly higher mycosis (sporulation) rate than endophytic treatments $(\mathrm{df}=5 ; P<$ 0.0001). In contrast, there were no significant differences (statistically) in larval sporulation among endophytic treatments (seed coating and/ or root soaking) $(\mathrm{df}=3 ; \mathrm{F}=0.25 ; P>$ 0.85). However, mean sporulation rates were generally higher on larval instar 3 than instar 2, while larval instar 4 had the lowest sporulation rate (Table 2). Referring to the influence of larval age in cadaver sporulation, there were no significant differences among larval instars (df $=2 ; P>0.084)($ Table 2$)$.

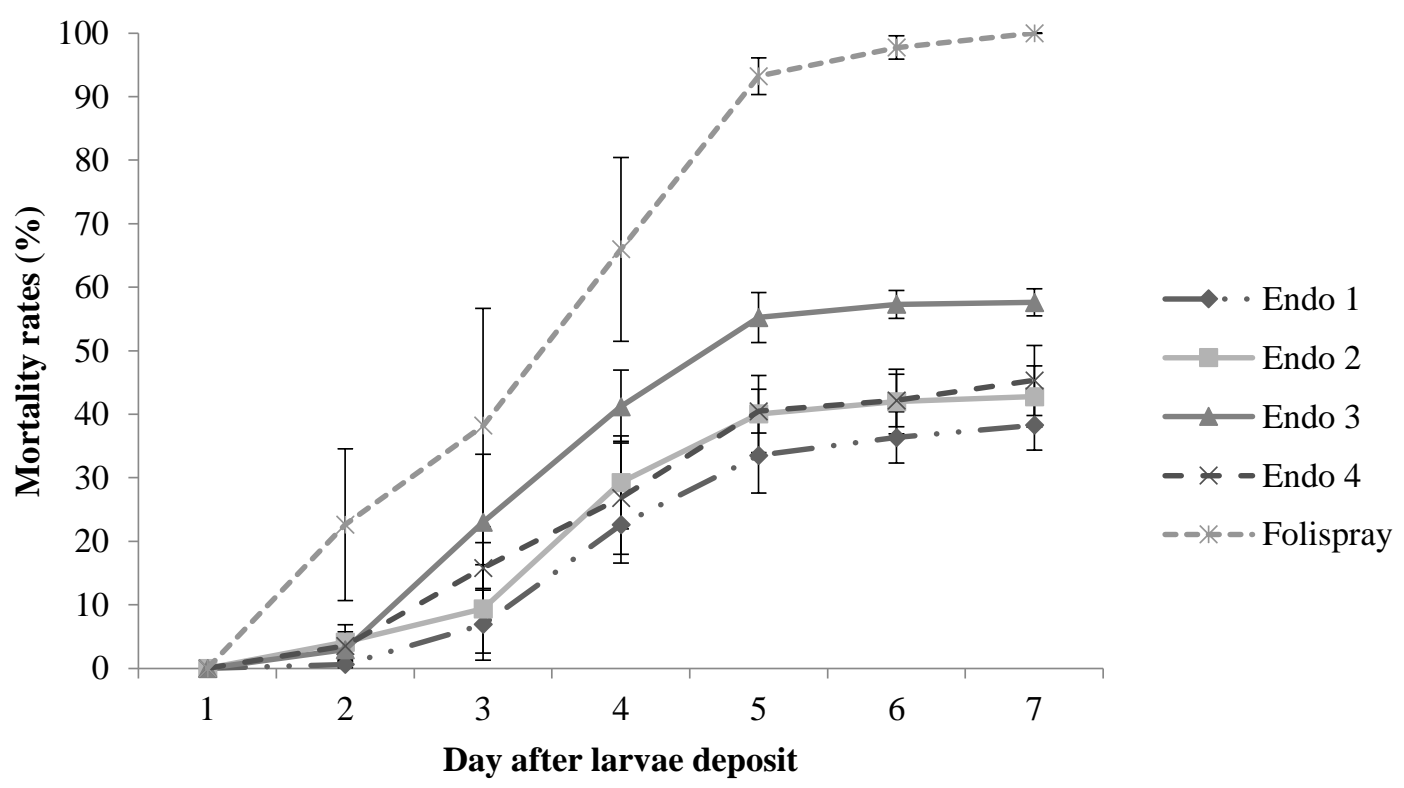

Figure 1: Temporal evolution of corrected mortality rates of P. xylostella larval instar 2 deposited on endophytic and foliar application plants.

(Untreated control mortality rates were used to correct mortality rates of treatments).

Endo 1: seeds coated and sown; seedlings not transplanted after emergence; Endo 2: seeds coated and seedlings transplanted; Endo 3: seeds coated and seedling roots dipped in B. bassiana conidia powder prior to transplantation; Endo 4: seeds not coated; seedlings roots dipped in B. bassiana conidia powder prior to transplantation; Folispray (Foliar spay): seeds not coated and roots not dipped in B. bassiana conidia powder; plants sprayed with a B. bassiana formulation $\left(10^{8}\right.$ spores.ml $\left.{ }^{-1}\right)$ before larvae deposit. 


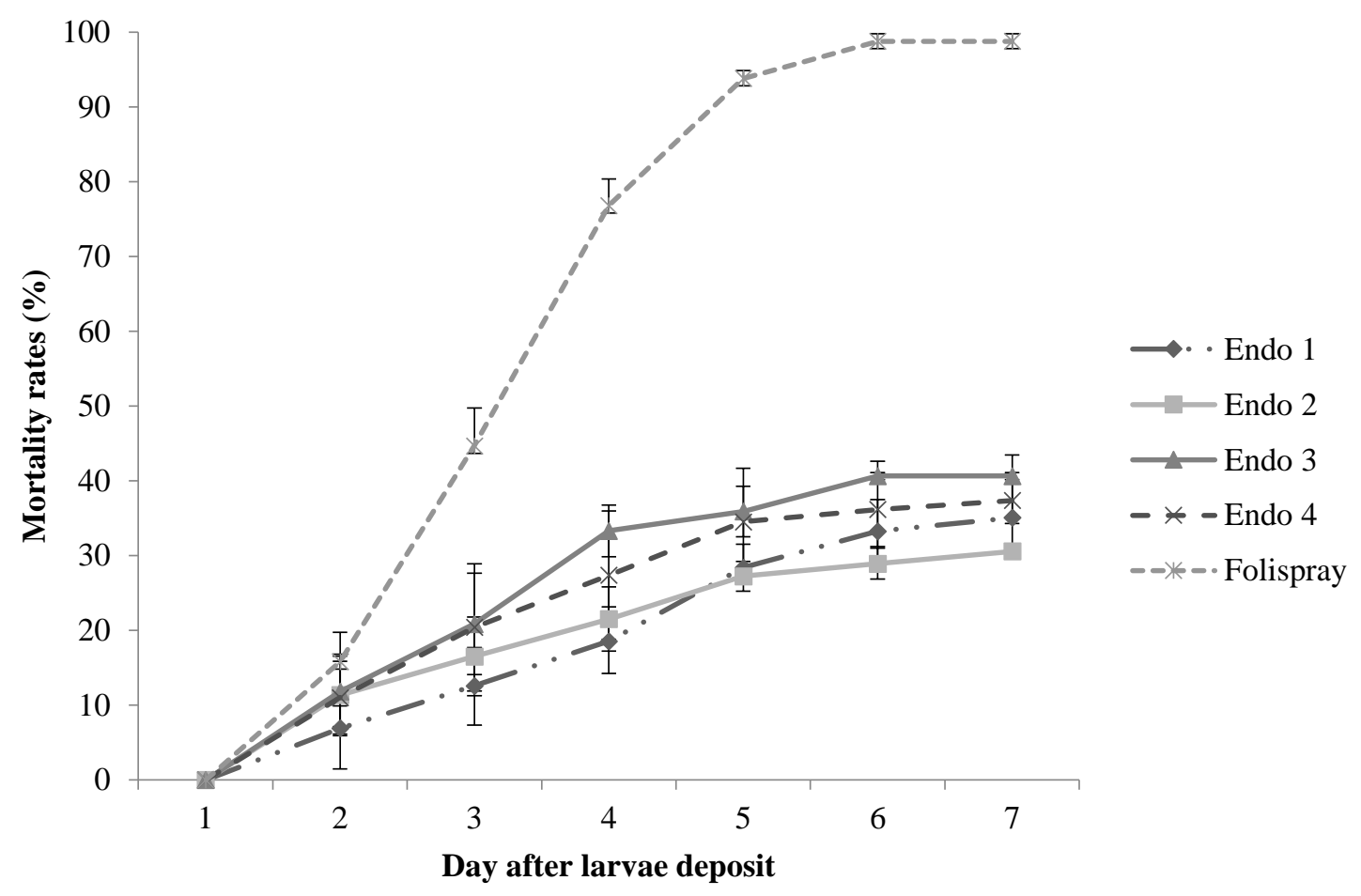

Figure 2: Temporal evolution of corrected mortality rates of $P$. xylostella larval instar 3 deposited on endophytic and foliar application plants.

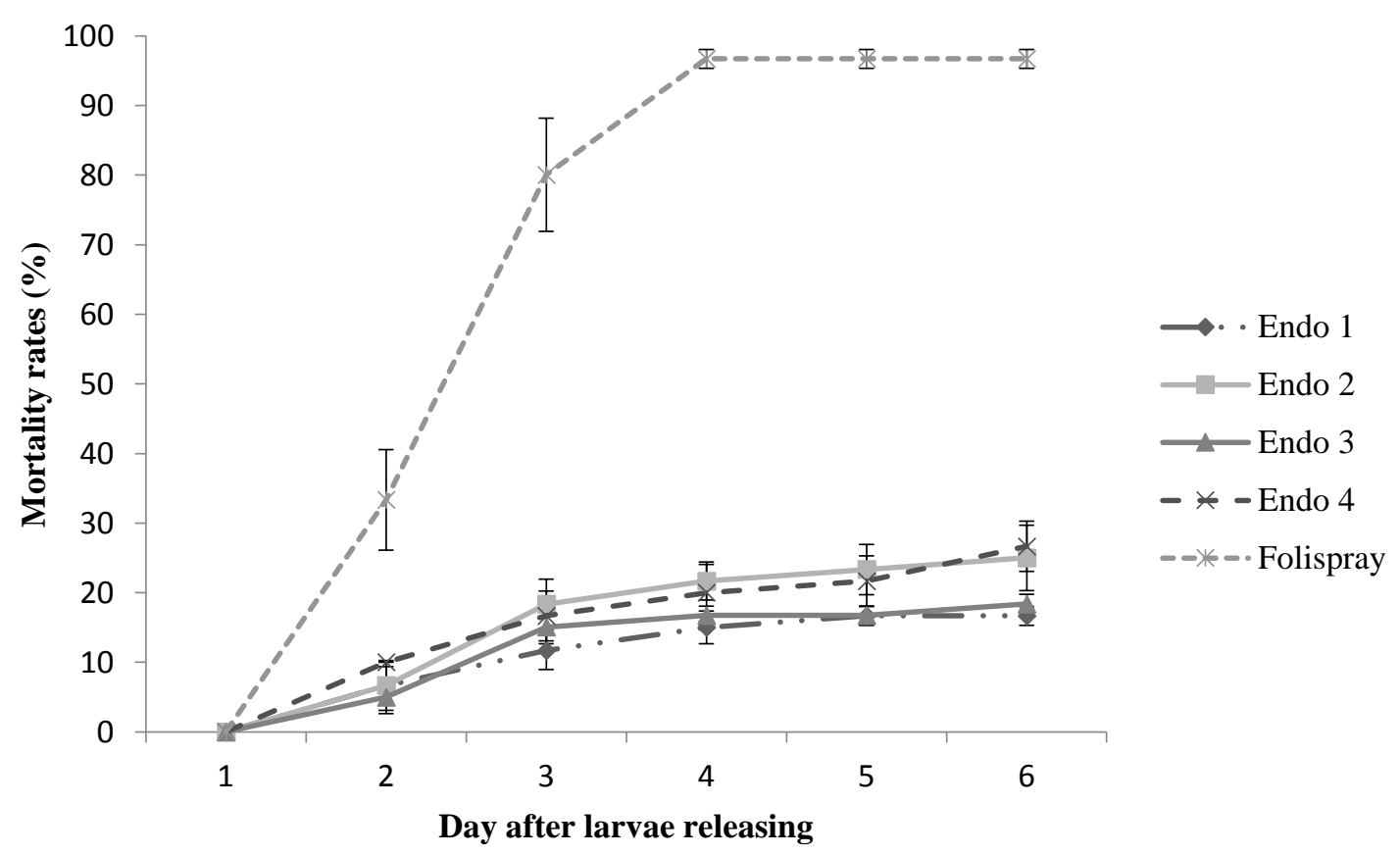

Figure 3: Temporal evolution of corrected mortality rates of $P$. xylostella larval instar 4 deposited on endophytic and foliar application plants. 
Table 1: Corrected average mortality rates of $P$. xylostella larvae six days after deposit on treated plant.

\begin{tabular}{cccccc}
\hline Treatments & \multicolumn{7}{c}{ Larval instars } \\
\hline & L 2 & L 3 & L 4 & $\boldsymbol{F}$ & $\boldsymbol{P}$ \\
\hline Endo 1 (E 1) & $38.27 \pm 3.93 \mathrm{cA}$ & $35.08 \pm 4.51 \mathrm{bA}$ & $16.67 \pm 1.36 \mathrm{bB}$ & 8.41 & $<0.018$ \\
Endo 2 (E 2) & $42.77 \pm 4.81 \mathrm{bcA}$ & $30.58 \pm 0.76 \mathrm{bA}$ & $25.00 \pm 4.71 \mathrm{bA}$ & 4.06 & $>0.077$ \\
Endo 3 (E 3) & $57.61 \pm 2.15 \mathrm{bA}$ & $40.65 \pm 0.48 \mathrm{bB}$ & $18.38 \pm 1.38 \mathrm{bC}$ & 75.25 & $<0.0001$ \\
Endo 4 (E 4) & $45.33 \pm 5.52 \mathrm{bcA}$ & $37.38 \pm 6.10 \mathrm{bA}$ & $26.67 \pm 3.60 \mathrm{bA}$ & 3.53 & $>0.097$ \\
foliar spray & $100.00 \pm 0.00 \mathrm{aA}$ & $98.78 \pm 0.99 \mathrm{aA}$ & $96.72 \pm 1.34 \mathrm{aA}$ & 1.98 & $>0.218$ \\
\cline { 2 - 7 } F & 21.22 & 22.15 & 16.32 & & \\
$P$ & $<0.001$ & $<0.002$ & $<0.0015$ & & \\
\hline
\end{tabular}

Means followed by the same letters a, b, c in the same column are not significantly different using Student-Newman-Keuls (SNK) at $P<0.05$.

Means followed by the same letters A, B, C in the same row are not significantly different using Student-Newman-Keuls (SNK) at $P<0.05$.

* Untreated control mortality rates were used to correct mortality rates of treatments

Endo 1: seeds coated and sown but seedlings not transplanted after emergence; Endo 2: seeds coated and seedlings transplanted; Endo 3: seeds coated and seedling roots dipped in B. bassiana conidia powder prior to transplantation; Endo 4: seeds not coated; seedlings roots dipped in B. bassiana conidia powder prior to transplantation; Foliar spay: seeds not coated and roots not dipped in B. bassiana conidia powder; plants sprayed with a $B$. bassiana formulation $\left(10^{8}\right.$ spores.ml $\left.^{-1}\right)$ before larvae deposit.

Table 2: Average sporulation rate of $P$. xylostella larval cadavers at the end of the trials.

\begin{tabular}{|c|c|c|c|c|c|}
\hline \multirow[t]{2}{*}{ Treatments } & \multicolumn{3}{|c|}{ Larval instars } & \multirow[b]{2}{*}{$F$} & \multirow[b]{2}{*}{$P$} \\
\hline & $L 2$ & $L 3$ & $L 4$ & & \\
\hline Endo 1 (E 1) & $7.58 \pm 3.36 \mathrm{bA}$ & $14.24 \pm 8.57 \mathrm{bA}$ & $0.00 \pm 0.00 \mathrm{bA}$ & 3.85 & $>0.084$ \\
\hline Endo 2 (E 2) & $8.88 \pm 6.21 \mathrm{bA}$ & $15.56 \pm 7.83 \mathrm{bA}$ & $0.00 \pm 0.00 \mathrm{bA}$ & 1.59 & $>0.279$ \\
\hline Endo 3 (E 3) & $20.66 \pm 12.60 \mathrm{bA}$ & $32.66 \pm 13.63 \mathrm{baA}$ & $16.67 \pm 13.61 \mathrm{bA}$ & 0.30 & $>0.75$ \\
\hline Endo 4 (E 4) & $15.86 \pm 10.35 \mathrm{bB}$ & $25.45 \pm 9.23 b$ & $18.76 \pm 0.00 \mathrm{~b}$ & 0.49 & $>0.64$ \\
\hline toliar spray & $93.89 \pm 2.76 \mathrm{aA}$ & $94.70 \pm 2.32 \mathrm{aA}$ & $93.33 \pm 5.44 \mathrm{aA}$ & 0.03 & $>0.97$ \\
\hline - & $0.00 \pm 0.00 \mathrm{bA}$ & $0.00 \pm 0.00 \mathrm{bA}$ & $0.00 \pm 0.00 \mathrm{bA}$ & & \\
\hline $\mathrm{F}$ & 7.37 & 5.18 & 15.41 & & \\
\hline$P$ & $<0.0023$ & $<0.0092$ & $<0.0001$ & & \\
\hline
\end{tabular}

Means followed by the same letters a, b, c in the same column are not significantly different using Student Newman Keuls (SNK) at $P<0.05$.

Means followed by the same letters A, B, C in the same row are not significantly different using Student Newman Keuls (SNK) at $P<0.05$. 


\section{DISCUSSION}

Our results confirmed that the isolate $\mathrm{Bb} 11$ of $B$. bassiana used for these experiments is pathogenic to $P$. xylostella larvae. The high mortality rates obtained by foliar applications are similar to those reported by several authors who have tested $B$. bassiana on various insects (Gindin et al., 2006; Godonou et al., 2009; James et al., 2010; Fancelli et al., 2013; Lopez et al., 2014; Toffa et al., 2014). Also, the corrected mortality rate $(57.61 \pm 2.15 \%)$ obtained with the endophytic inoculation in our study is similar to those reported by Batta (2013) in endophytic M. anisopliae applied against larvae of $P$. xylostella infesting Brassica napus plants, and comparable to results by Vidal and Jaber (2015) using endophytic B. bassiana in B. napus and Vicia faba against Helicoverpa armigera (Hübner) (Lepidoptera: Noctuidae). In this study, the range of larval mortalities was similar to the range reported by Valda et al. (2003).

The high larval mortality and sporulation rates observed in foliar applications can be explained by the high number of fungal conidia that must have been in direct contact with the cuticle of the larvae and hence germinated and invaded their haemocœl, thereby inducing mycosis (Butt et al., 2016). In the endophytic colonization treatments, however, we assumed that $B$. bassiana was translocated systemically through the plant tissues (Raja et al., 2016) and that larval infection occurred through ingestion of its hyphae in the palisade parenchyma of cabbage leaf tissues (Heviefo et al., 2017), with no direct exposure to conidia. Subsequently, the ingested ramified hyphae would have developed in the haemocœl of the infected larvae thereafter producing spores and toxins (Ownley et al., 2010) that induced lower levels of mortality and sporulation compared with the foliar applications, as also reported by Butt et al. (2016) and (Ortiz-Urquiza et al., 2010) and could explain why we only observed $57.61 \pm$ $2.15 \%$ corrected larval mortality rate in the endophytic treatment (Endo 3) instead of 100\% mortality induced by foliar application, as also reported by Butt et al. (2016).
The mortality rates recorded with the endophytic treatement 3 (Endo 3) showed significant variation among $P$. xylostella larval instars. whereby younger larvae were more susceptible than the elder ones. This is in support to the results by Douro-Kpindou et al. (2012) on H. armigera and Toffa et al. (2014) on $M$. vitrata. It appears that immature stages of $P$. xylostella are able to boost their immune systems with age thereby increasing their capacities of detoxification (Butt et al., 2016). Seed coating + root soaking (treatment 3) yielded the best endophytic colonization of cabbage leaves (Heviefo et al., 2017) with the highest mortality of $P$. xylostella larvae.

To explain the lower sporulation rates recorded with endophytic application of $B$. bassiana, we can speculate that fungal hyphae must grow, kill the host larva, ramify, colonize the haemocol cavity of the cadaver and penetrate through the external larvae cuticle before producing conidia, thereby inducing mortality of the host, as observed by Butt et al. (2016). In addition, with this complex process, the fungus must overcome the internal larval resistance before achieving its development within the host-insect. It, therefore, contrasts with the direct spraying of conidia suspensions where many more fungal spores can adhere to the cuticle of the host and germinate in a shorter time. This mechanism could also explain why larval instar 4 is resistant to endophytical treatments but still very vulnerable to epiphytical treatments of $B$. bassiana. Irrespective of the application method, larval instar 3 displayed the highest sporulation rates, certainly due to its relatively better nutritional properties (compare with instars 2 and 4), for B. bassiana development, as reported in other studies (Sapna and Anushree, 2013).

In spite of all the inconveniencies linked with the relatively lower mortality of the hosts, endophytic fungus applications might be more friendly with the ecosystem stabilityespecially, with regard to non-target effects on beneficial-arthropods than direct spraying of conidial formulations (Azevedo et al., 2000). While we now have an empirical evidence that endophytic $B$. bassiana constitutes a valuable 
approach in $P$. xylostella management, the metabolic pathways underlying the exact mechanisms of action of endophytism still remain to be elucidated.

\section{Conclusion}

From this study, it can be concluded that the isolate $\mathrm{Bb} 11$ of $B$. bassiana is pathogenic to $P$. xylostella larvae. In endophytic treatments, larval mortality rates varied with larval age. B. bassiana can be used as well as endophyte as foliar application for the management of $P$. xylostella pest. The results from this study suggest that seed coating + root soaking (treatment 3) yielded the beneficial mortality of $P$. xylostella larvae for plant protection. But the foliar application of $B$. bassiana decimates all larval instars in contrast of endophytic applications. Then, B. bassiana endophytic applications might be more friendly with the ecosystem stability.

\section{COMPETING INTERESTS}

All authors declare that they have no competing interests with this manuscript.

\section{AUTHORS' CONTRIBUTIONS}

GAH was the principal investigator and prepared the manuscript. IAG, SWN and MT supervised the work, guided, structured and corrected the manuscript; BDD helped for trials monitoring and earlier drafts writing.

\section{ACKNOWLEDGMENTS}

We thank Mr Etienne Dagbozounkou for technical assistance and Dr Pierre-Louis Amoussou for reviewing earlier drafts of the manuscript.

\section{REFERENCES}

Abbott WS. 1925. A method of computing the effectiveness of an insecticide. J. Econ. Ent., 18: 265-267.

Agboyi KL, Ketoh KG, Martin T, Glitho IA, Tamò M. 2016. Pesticide resistance in Plutella xylostella (Lepidoptera: Plutellidae) populations from Togo and Benin. International journal of Tropical Insect Science, 36: 204-210.
Azevedo JL, Maccheroni WJ, Pereira JO, de Araùjo WL. 2000. Endophytic microorganisms: a review on insect control and recent advances on tropical plants. Biotechnology, 3: $40-65$.

Batta YA. 2013. Efficacy of endophytic and applied Metarhizium anisopliae (M) Sorokin (Ascomycota: Hypocreales) against larvae of Plutella xylostella L. (Yponomeutidae: Lepidoptera) infesting Brassica napus plants. Crop Protection, 44: 128 - 144.

Benkhelil A, Grancher D, Giraud N, Bezille, P, Bony S. 2004. Intoxication par des toxines de champignons endophytes chez les taureaux reproducteurs. Méd. Vét., 156: $243-247$.

Butt TM, Coates CJ, Dubovskiy IM, Ratcliffe NA. 2016. Entomopathogenic Fungi: New Insights into Host-Pathogen Interactions. Advances in Genetics, 94: 158.

Cheema HK, Kang BK, Singh B. 2011. Biochemical and molecular basic of insecticide resistance in diamondback moth, Plutella xylostella (Linnaeus): a review. Pesticide Research Journal, 23: 123-134.

Douro-Kpindou OK, Djegui AD, Glitho Adolé I, Tamò M. 2012. Sensiblity of Helicoverpa armigera (Hübner) (Lepidoptera: Noctuidae) to the entomopathogenic fungi Metarhizium anisopliae and Beauveria bassiana in laboratory. ARPN Journal of Agricultural and Biological Science, 7: 1007-1015.

Fancelli M, Dias AB, Delaliber IJ, de Jesus SC, do Nascimento AS, Silva SO, Caldas RC, Ledo CA. 2013. Beauveria bassiana strains for biological control of Cosmopolites sordidus (Germ.) (Coleoptera: Curculionidae) in plantain. Biomed Res Int., DOI: 10.1155/2013/184756.

Gindin G, Levski S, Soroker V. 2006. Evaluation of the entomopathogenic fungi Metarhizium anisopliae and Beauveria bassiana against the red palm weevil Rhynchophorus ferrugineus. Entomology, 34: 370-379. 
Gnago JA, Danho M, Agneroh AT, Fofana KI, Kohou GA. 2010. Efficacité des extraits de neem (Azadirachta indica) et de papayer (Carica papaya) dans la lutte contre les insects ravageurs du gombo (Abelmoschus esculentus) et du chou (Brassica oleracea) en Côte d'Ivoire. Int. J. Biol. Chem. Sci., 4: 953-966.

Godonou I, James B. Atcha-Ahowe C, Vodouhè S, Kooyman C, Ahanchédé A, Korie S. 2009. Potential of Beauveria bassiana and Metarhizium anisopliae isolates from Benin to control Plutella xylostella L. (Lepidoptera: Plutellidae). Crop protection, 28: 220-224.

Heviefo AG, Nyamador SW, Glitho IA, Tamò M. 2017. Establishment of the fungal entomopathogen Beauveria bassiana as endophyte in cabbage plant for disease and lepidopteran larvae pest control. Bulletin de la Recherche Agronomique du Bénin (BRAB). Numéro Spécial Développement Agricole Durable (DAD), Décembre $2017: 1$ - 12.

Heviefo AG, Nyamador SW, Dagbozounkou ED, Tamó M, Glitho IA. 2018. Influence de la temperature et de la nature du substrat sur la production en masse et la conservation de Beauveria bassiana B., champignon entomopathogène. CAMES Science de la vie, de la terre et agronomie, Rev. Ramres, $6: 36$ - 44.

James B, Godonou I, Atcha-Ahowé C, Baimey H. 2006. Summary of activities and achievements, 2003- 2006, Healthy vegetables through participatory IPM in peri-urban areas of Benin, International Institute of Tropical Agriculture (IITA), Cotonou, Benin. 134p.

James B, Atcha-Ahowé C, Godonou I, Baimey H, Goergen G, Sikirou R, Toko M. 2010. Gestion Intégrée des Nuisibles en Production Maraîchère : Guide pour les Producteurs de Vulgarisation en Afrique de l'Ouest. Green Ink Ltd : 112 p.

Kfir R. 2005. The Impact of Parasitoids on Plutella xylostella populations in South Africa and the successful Biological Control of the pest on the island of ST. HELENA. Second International
Symposium on Biological Control of Arthropods: 132-141.

Komlan AF, Simon S, Ajaïto L, Agbozo R, Mensah G, Ahouandjinou C, Ngouafio M, Martin T. 2014. Evaluation de l'effet de cinq différentes couleurs de filets antiinsectes sur la lutte contre les ravageurs et la productivité du chou (Brassica oleracea) au Sud-Bénin. Bulletin de Recherche Agronomique du Bénin, 76 : 18.

Liu X, Chen M, Collins HL, Onstad DW, Roush RT. 2014. Natural Enemies Delay Insect Resistance to $B t$ Crops. PLoS ONE, 9(3): $\quad$ e90366. DOI: 10.1371/journal.pone.0090366.

Lopez DC, Zhu-Salzman K, Ek-Ramos, Sword AG. 2014. The entomopathogenic fungal endophytes Purpureocillium lilacium (Formerly Paecilomyces lilacinus) and Beauveria bassiana negatively affect cotton Aphid reproduction under both greenhouse and field conditions. PLOS ONE, 9: 7p.

LUBILOSA. 1996. Laboratory techniques in insect pathology. Technical bulletin, 3: 140.

Mondédji AD. 2010. Potentiel d'utilisation d'extraits de feuilles de neem (Azadirachta indica A. Juss) et de papayer (Carica papaya L.) dans le contrôle des insectes ravageurs du chou (Brassica oleracea L.) en zones urbaine et périurbaines au Sud du Togo. Thèse de Doctorat unique, Université de Lomé, Lomé, p. 247.

Mondedji DA, Nyamador SW, Amevoin K, Ketoh KG, Glitho AI. 2014. Efficacité des extraits de feuilles de neem Azadirachta indica (Sapindale) sur Plutella xylostella (Lepidoptera: Plutellidae), Hellula undalis (Lepidoptera: Pyralidae) et Lipaphis erysimi (Hemiptera : Aphididae) du chou Brassica oleracea (Brassicaceae) dans une approche «Champ Ecole paysan » au sud du Togo. International Journal of Biological and Chemical Sciences, 8: 2286-2295. 
Ortiz-Urquiza A, Riveiro-Mirands L, SantiagoAlvarez E, Quesada-Moraga E. 2010. Insect-toxic secreted proteins and virulence of entomopathogenic fungus Beauveria bassiana. Invertebrate Pathology, 105: 270-278.

Ownley BH, Gwinn KD, Vega FE. 2010. Endophytic fungal entomopathogens with activity against plant pathogens: ecology and evolution. BioControl, 55: 113 - 128.

Raja S, Subhashini P, Thangaradjou T. 2016. Differential methods of localisation of fungal endophytes in the seagrasses. Mycology, an International Journal on Fungal Biology, 7: 112-123.

Rasmussen S, Liu Q, Parsons AJ, Xue H, Sinclair B, Newman JA. 2012. Grassendophyte interactions: a note on the role of monosaccharide transport in the Notyphodium lolii-Lolium perenne symbiosis. New Phytologist, 196: 7-12.

Sane B, Badiane D, Gueye MT, Faye O. 2018. Evaluation de l'efficacité biologique d'extrait de neem (Azadirachta indica Juss.) comme alternatif aux pyréthrinoïdes pour le contrôle des principaux ravageurs du cotonnier (Gossypium hirsutum L.) au Sénégal. Int. J. Biol. Chem. Sci., 12(1): 157-167.

Sapna M, Anushree M. 2013. Nutritional optimization of a native Beauveria bassiana isolate (HQ917687) pathogenic to housefly, Musca domestica L. J Parasit Dis., 37(2): 199-207.

Tamò M, Srinivasan R, Dannon E, Agboton, C, Datinon B, Dabire C, Baoua I, Ba MN, Haruna B, Pittendrigh BR. 2012. Biological control: a major component for the long-term cowpea pest Management strategy. pp 249-259. In: Boukar O, Coulibaly O, Fatokun C, Lopez K, Tamò M.(eds.). Enhancing cowpea value chains through research advances. Proceedings of the $5^{\text {th }}$ World Cowpea Research Conference, 26 September - 1 October 2010 Saly, Senegal.

Tidjani OMM, Issoufou A, Rabani A, Zeinab SS. 2018. Contamination potentielle des aliments par des polychlorobiphényles (PCBs): Connaissance du polluant et évaluation de la perception du risqué. Int. J. Biol. Chem. Sci., 12(1): 168-179.

Toffa MJ, Atachi P, Douro KOK, Tamò M. 2014. Pathogenicity of Metarhizium anisopliae and Beauveria bassiana on larvae of the legume pod borer Maruca vitrata (Lepidoptera: Crambidae). Journal of Agricultural and Biological Science, 9: 55-64.

Valda CA, Reginaldo B, Edmilson JM, Jorge BT. 2003. Susceptibility of Plutella xylostella (L) (Lepidoptera: Plutellidae) to the fungi Beauveria bassiana (B) and Metarhizium anisopliae (M). Entomol., 32: 653 - 658 .

Vega FE, Posada F, Aime MC, Pava-Ripoli M, Infante F, Rehner SA. 2008. Entomopathogenic fungal endophytes. Biological Control, 46: $72-82$.

Vidal S, Jaber LR. 2015. Entomopathogenic fungi as endophytes: plant-endophyteherbivore interactions and prospects for use in biological control. Current Science, 109: 46-54. 